\title{
Prezentacje
}

\section{Naukowcy i antropos. Antropocen czy oligantropocen?'}

Christophe Bonneuil, Jean-Baptiste Fressoz

TEKSTY DRUGIE 2020, NR 1, S. 186-203

DOI: $10.18318 /$ td.2020.1.10

$\mathbf{O}$ ficjalna narracja antropocenu podejmuje nie tylko kwestię wyjątkowości Ziemi, którą z przestrzeni kosmicznej wszyscy powinniśmy postrzegać w jednolity sposób, ale także ludzkości jako jednostki biologicznej oraz czynnika geologicznego. W ten sposób poznajemy dwóch zasadniczych aktorów: gatunek ludzki z jednej strony i system Ziemi z drugiej; historia antropocenu opowiada o ich wzajemnych oddziaływaniach poprzez tysiące zapętlonych akcji i reakcji. Wielka narracja antropocenu staje się narracją o „przemianie ludzi łowców-zbieraczy w globalną siłę geofizyczną"2. Zwolennikom antropocenu nie pozostaje zatem nic innego, jak tylko ogłosić się przewodnikami „ludzkości”, której zbywa na wiedzy, zalecając jej, by „na nowo połączyła się

1 Podstawą tłumaczenia są fragmenty rozdziału "Le savant et l'antrophos: Anthropocène ou Oliganthropocène" z książki: Ch. Bonneuil, J.-B. Fressoz L'Événement Anthropocène. La Terre, l'histoire et nous, Éditions du Seuil, Paris 2016, s. 83-118.

2 W. Steffen, P.J. Crutzen, J.R. McNeill The Anthropocene: Are Humans Now Overwhelming the Great Forces of Nature?, "Ambio" 2007 No. 8, s. 614 .

\section{Chrisophe \\ Bonneuil - histo- \\ ryk i antropolog \\ nauki, autor kilkunastu \\ wpływowych książek \\ poświęconych związ- \\ kom wiedzy, polityki \\ i społeczeństwa, pro- \\ blemom zmian klima- \\ tycznych i kwestiom \\ antropocenu; pracuje \\ w CNRS w Paryżu.}

\section{Jean-Baptize}

Fressoz - historyk nauki, teoretyk środowiska, antropocenu i nowoczesności w perspektywie zmian technologicznych i klimatycznych. Autor kilkunastu prac i manifestów poświęconych tym zagadnieniom; pracuje w CNRS w Paryżu. 
z biosferą"3. Przeanalizujmy zatem tę wizję antroposu naszych ekspertów od antropocenu oraz jej główne założenia.

\section{Odyseja gatunku}

„Ludzkość, nasz własny gatunek, stała się tak liczna i aktywna, że zaczęła rywalizować z wielkimi siłami Natury w wywieraniu wpływu na funkcjonowanie systemu Ziemi".

Oto serce bezdyskusyjnego założenia antropocenu. Założenie to jednak generuje ideę połączenia wszystkich ludzkich działań w jedna „aktywność ludzką" odpowiedzialną za „wpływ ludzki” na Ziemię. Warto to poddać dyskusji. Kluczowy artykuł opublikowany w „Philosophical Transactions” na temat antropocenu i jego historii zawiera co najmniej 99 przypadków użycia przymiotnika „ludzki” bądź rzeczownika „ludzkość”. Dominująca narracja zwolenników antropocenu tworzy abstrakcyjną ludzkość, jednakowo zatroskaną, czyli, domyślnie, jednakowo odpowiedzialną. [...]

Należy jednak uważać, by pilne względy ekologiczne bądź zależności społeczno-ekosystemowe nie doprowadziły do pominięcia zdobyczy nauk humanistycznych. Od marksistowskiej idei klasy po antropologię Claude'a Lévi-Straussa, studia feministyczne oraz postkolonialne, nauki te podważały stary uniwersalizm „Człowieka” i akcentowały zarówno równą godność, jak i różnorodność kultur, społeczeństw, klas społecznych i tożsamości płciowych. Próbowały też zdemaskować mechanizmy dominacji, przez które wybrane wspólnoty niszczą, wykorzystują bądź podporządkowują sobie inne, tworząc asymetryczne struktury społeczne.

Przypadek antropocenu wstrząsnął naukami humanistycznymi i społecznymi, zachwiał ich paradygmatami i kategoriami. Czy to nie badacze zajmujący się nauką o systemie Ziemi, a nie historycy, nazywają epokę, w której żyjemy? Czy dla humanistyki środowiskowej konieczność myślenia o ludzkiej aktywności także w geologicznej skali dziesiątek tysięcy lat nie jest zawrotem głowy i nie oznacza utraty punktów odniesienia? [...]

Ten zawrót głowy humanistyki w obliczu antropocenu, ta trudność połączenia fenomenów historycznych i społecznie zróżnicowanych z przyszłością

3 C. Folke, L. Gunderson Reconnecting to the Biosphere:A Social-Ecological Renaissance , Ecology and Society" 2012 No. 4, S. 55.

4 W. Steffen, J. Grinevald, P.J. Crutzen, J.R. McNeill The Anthropocene: Conceptual and Historical Perspectives, "Philosophical Transactions of the Royal Society A” 2011 No. 369, s. 843. 
planety (czyli ze wspólnymi, choć niejednorodnymi dla ludzi konsekwencjami) pojawiają się także w kluczowych narracjach o kryzysie środowiska naturalnego. Według ważnych autorów, w sposób eksplicytny bądź implicytny, nasze ekologiczne kłopoty mają swe źródło w nowoczesności. Pod piórem tych autorów odnajdujemy wszystkich usual suspects wielkiego fresku intelektualnej historii Zachodu: najpierw nauka grecka, która postrzega naturę jako coś zewnętrznego i podległego prawom niezależnym od ludzkich intencji; potem chrześcijaństwo, mówiące o wyjątkowości człowieka pośród Stworzenia, które winien on sobie podporzą dkować; wreszcie naukowa rewolucja, zastępująca organicystyczną wizję natury koncepcją bezwładnego mechanizmu, który można w racjonalny sposób modyfikować. Czynnik eschatologiczny kryzysu środowiska naturalnego zmusza ich do tworzenia ogromnych i majestatycznych opowieści, które podkreślają hipotetyczny charakter „wielkiego podziału", wielkiej separacji człowieka od reszty istnień.

Porwani przez wicher Gai, najważniejsi socjologowie i filozofowie zaczęli wyrzucać za burtę „okrętu Ziemia” cały arsenał analityczny, wyjaśniający i krytyczny nauk humanistycznych i społecznych. [...] Można nawet napisać całą książkę na temat kryzysu środowiska naturalnego, polityk natury, antropocenu i sytuacji Gai, nie wspominając o kapitalizmie, wojnach lub Stanach Zjednoczonych oraz nie wymieniając nazwy choćby najmniejszego spośród wielkich przedsiębiorstw (choć statystyki są wymowne: 90 przedsiębiorstw jest odpowiedzialnych za $63 \%$ łącznej emisji $\mathrm{CO}_{2}$ i metanu od 1850 roku do dziś). [...]

W oczywisty sposób antropocen jako koncept zrodzony przez nauki o systemie Ziemi usiłuje pogodzić wątpliwości historyczne z interesem tych nauk. Według naszych antropocenologów rola historii ogranicza się do badania wpływu aktywności ludzkiej na system Ziemi w celu jej włączenia do modelu, a następnie sprawdzenia oddziaływania modelu na wydarzenia z przeszłości. Jest to perspektywa przyjęta w projekcie IHOPE, Integrated History and Future of People on Earth. Słowa klucze to $\mathrm{w}$ tym przypadku: cykle biogeochemiczne, integracja (danych, systemów, dyscyplin), kompleksowość i układy nieliniowe. Historia mogłaby tu gwarantować pewną dozę nieprzewidywalności [...],jednak ostatecznie jej rezultaty są dość łatwe do przewidzenia: antropocen jest wytworem ogólnego wzrostu populacji, rozwoju rolnictwa, przemysłu, wyrębu lasów, działalności kopalń oraz PKB. [...]

Najdziwniejsze w tym szumnym powrocie "gatunku ludzkiego" do historii jest to, że antropocen pozwala jednocześnie stwierdzić, iż ze środowiskowego 
punktu widzenia ludzkość jako całość nie istnieje. Kim bowiem jest antropos, ten generyczny ludzki byt w narracji antropocenu? Czyż nie jest wewnętrznie niejednorodny, z różnie rozłożoną odpowiedzialnością za globalny kryzys ekologiczny? Czy statystyczny Amerykanin nie spożywa 32 razy więcej zasobów i energii niż statystyczny Kenijczyk? Czy nowy człowiek rodzący się na Ziemi nie będzie miał tysiąc razy większego śladu węglowego, jeśli przyjdzie na świat w zamożnej rodzinie w bogatym państwie, niż gdyby urodził się w ubogiej rodzinie w biednym kraju? Czy indiańskie plemię Janomamów, którzy polują, łowią i uprawiają ziemię w amazońskich lasach i pracują trzy godziny dziennie, nie używając paliw kopalnych (a mimo to ich zasiewy dają plony dziewięć razy wyższe niż ziemie uprawiane przez rolników w Beauce), musi się czuć odpowiedzialne za zmiany klimatyczne i antropocen? Niedawno opublikowany raport dowodzi, że $1 \%$ najbogatszych ludzi na planecie posiada na wyłączność $48 \%$ światowego bogactwa, natomiast najuboższa połowa ludzkości musi zadowolić się $1 \%^{5}$. Osiemdziesięcioro najbogatszych ludzi świata gromadzi zyski wyższe niż 416 milionów najuboższych: każdy z nich zarabia zatem więcej niż milion jego współbraci! Tego rodzaju nierówności są najgłębszym źródłem globalnego kryzysu ekologicznego, ponieważ najbogatsi ustalili poziom konsumpcji, który chcieliby osiągnąć ci gorzej sytuowani, zgodnie z teorią łańcucha naśladowania zaproponowaną w 1899 roku przez Thorsteina Veblena ${ }^{6}$. Wynika z tego, co ostatnio pokazali ekonomiści, że polityka opodatkowania najbogatszych jest korzystna dla środowiska.

W zasadzie należałoby wraz z Erikiem Swyngendouw mówić raczej o oligantropocenie, czyli epoce geologicznej wywołanej przez niewielki odłam ludzkości, niż o antropocenie. Wybór tego ostatniego terminu i powiązanej z nim wielkiej narracji ukrywa, za abstrakcyjną kategorią „ludzkiego gatunku”, ogromne zróżnicowanie odpowiedzialności i relacji między klasami, płciami i narodami Gai. Taka stronniczość nie pozostaje bez wpływu na wybór „rozwiązania" problemów ekologicznych, które nie są sankcjonowane w narracji antropocenologów. Kluczowy artykuł w „Philosophical Transactions” jest dowodem ukrywania tych asymetrii, które są w nim jedynie wspomniane

5 Zob. raport Global Wealth Databookudostępniony przez Crédit Suisse w 2014 roku, https:/publicalions.credit-suisse.com/tasks/render/file/?fileID $=5521 F 296-D 460-2 B 88-081889 D B 12817$ E02 (22.02.2016).

6 Zob. T. Veblen The Theory of the Leisure Class, Oxford University Press, Oxford 2009. Przekład polski: T. Veblen Teoria klasy próżniaczej, przeł. J. Frentzel-Zagórska, Muza, Warszawa 1998. 
od niechcenia, w urzekającej nowomowie: „problemy kapitałowe wzrosły w antropocenie"7.

Powinniśmy zatem być nieufni wobec narracji antropocenu jako narracji o wzajemnych związkach gatunku ludzkiego i systemu Ziemi. Narracja ta prowadzi raczej do zubożałych bądź fałszywych wyjaśnień historycznych, które wzmacniają interesy mniejszości mieszkańców planety. Tymczasem wyzwaniem dla antropocenu jest zróżnicowana wizja ludzkości. I to nie jedynie przez wzgląd na prawdę historyczną bądź możliwość osądzenia przeszłej odpowiedzialności, ale także na realizację przyszłych, bardziej skutecznych i sprawiedliwych polityk; by stworzyć wspólny świat, w którym nie napominałoby się zwykłych ludzi, a przestępstw ekologicznych wielkich koncernów nie pozostawiałoby się bezkarnych; świat, w którym mieszkańcy wysp zagrożonych przez zmiany klimatyczne mieliby prawo żyć na własnych ziemiach bez obawy, że ich mała liczba przyczyni się do ich statystycznego i politycznego nieistnienia; świat, w którym mogłoby dalej istnieć 30000 osób żyjących we wspólnotach zbieracko-łowieckich zagrożonych wymarciem do 2030 roku. Ponieważ bogactwo ludzkości oraz jej zdolność przyszłej adaptacji są pochodną różnorodności jej kultur, będących eksperymentami, których celem jest godne zamieszkiwanie Ziemi.

\section{„Nie wiedzą, co czynią": narracja o przebudzeniu świadomości środowiskowej} "Ojcze, przebacz im, bo nie wiedzą, co czynią", możemy przeczytać w Ewangelii św. Eukasza. Są to słowa Chrystusa przybitego do krzyża. Rzecz jasna ludzie przyzwolili na egzekucję Zbawiciela, jednak ludzkość nie jest nieodwołalnie skazana, jak mogłaby być w Starym Testamencie, wygnana z rajskiego ogrodu. Zbawienie jest możliwe dzięki nawróceniu i wierze.

Dwa stulecia temu Charles Fourier sięgnął po retorykę objawienia i przebaczenia, by głosić „fizyczne zniszczenie planety”:

Ta prawda jest bardziej oczywista dla nowożytnych niż dla starożytnych; tym ostatnim, nowicjuszom w społecznym rozwoju, można wybaczyć, że się oszukiwali [...], jednak po scenach, które od 3000 lat zapewnia nam historia, mamy zbyt wiele doświadczeń związanych ze szkodliwym działaniem Cywilizacji i nie możemy pozwolić, by uczciwi ludzie przeczyli, że

7 W. Steffen, J. Grinevald, P.J. Crutzen, J.R. McNeill The Anthropocene: Conceptual and Historical Perspectives, s. 856. 
jest ona plagą ludzkości, że obecny stan planety jest prawdziwym piekłem fizycznym i społecznym, oraz że rozum, bez zwłoki, powinien poszukać wyjścia z tej sytuacji. ${ }^{8}$

Dwa stulecia po Fourierze, narracja antropocenu funkcjonuje w podobny sposób: jeśli „nowożytni” zbłądzili, niszcząc planetę, trzeba im wybaczyć, ponieważ nie wiedzieli, co czynili. Nie dysponowali ani nauką, ani świadomością globalnych i geologicznych konsekwencji ich działań. Niech tylko nowożytni przyjmą słowo antropoceniczne, a otrzymają rozgrzeszenie, a może nawet dostąpią zbawienia.

Wielka narracja antropocenu jest więc narracją przebudzenia. Po długim okresie nieświadomości, od 1750 roku po koniec XX wieku, nastał czas nagłego olśnienia. „Jesteśmy pierwszym pokoleniem, posiadającym szeroką wiedzę na temat tego, w jaki sposób nasza aktywność wpływa na system Ziemi", głoszą antropocenolodzy. „Problemy środowiska o zasięgu globalnym nie były w centrum zainteresowania w głównym okresie Wielkiego Przyspieszenia [po 1945], mimo że się pojawiały, ignorowano je"10, kontynuują. James Lovelock potwierdza, że „przekształcając środowisko, wypowiedzieliśmy bezwiednie wojnę systemowi Ziemi [wyróż. aut.]"11. [...]

Ważni filozofowie uczestniczą w tym wzniosłym koncercie żalów: wcześniej nie uświadamiano sobie globalnego wymiaru natury, oddzielano go od społeczeństwa, redukowano do zewnętrznej dekoracji działań człowieka. Według Michela Serresa dopiero wraz z perturbacjami klimatycznymi dostrzeżonymi pod koniec XX stulecia „nastąpiła erupcja natury w naszej kulturze, która do tej pory wyobrażała sobie tę naturę jak coś lokalnego i nieokreślonego, ozdobnego. Niegdyś lokalna - ta rzeka, to trzęsawisko; od tej pory globalna - Planeta Ziemia"12. [...]

Naukowcy i filozofowie, antropocenolodzy mówią więc o „nas" lub o „nich” z przeszłości, którzy nic nie robili i niczego nie wiedzieli. Akcent położony na

8 Ch. Fourier Détérioration matérielle de la planète, w: R. Schérer L'Écosophie de Chartes Fourier. Deux textes inédits, Anthropos, Paris 2001, s. 81.

9 W. Steffen i in. The Anthropocene: From Global Change to Planetary Stewardship, "Ambio" 2011, nr 40, s. 757. W. Steffen, J. Grinevald, P.J. Crutzen, J.R. McNeill The Anthropocene: Conceptual and Historical Perspectives, s. 850, 853 .

11 J. Lovelock The Revenge of Gaia, Allen Lane, London 2006, S. 13. 
radykalne zerwanie jest cechą retoryczną wszystkich wypowiedzi profetycznych, które podejmują ideę przyjścia. Narracja antropocenu też nie jest od niej wolna.

Jednak ten binarny schemat narracyjny jest również wytworem wielkich teorii socjologicznych i filozoficznych, które przeciwstawiają rzekomo bezrefleksyjny moment nowoczesności (od XVIII do XX wieku) rozkwitowi pod koniec XX stulecia refleksji nad ubocznymi skutkami modernizacji: zagrożenia sanitarne, katastrofy, kryzys środowiska. Jest to zwłaszcza teza Anthony'ego Giddensa dotycząca nastania „nowoczesności refleksyjnej” i Ulricha Becka teoria „społeczeństwa ryzyka”, zapowiadająca koniec rzekomej niewinności związanej z ubocznymi skutkami postępu $[\ldots]^{13}$. To również perspektywa zwolenników teorii modernizacji ekologicznej.

$\mathrm{Z}$ tej binarnej narracji można także wyodrębnić upraszczającą tezę, zgodnie z którą nowoczesność ustaliła wyraźny podział między naturą a społeczeństwem, podział, który uniemożliwia nam zrozumienie kwestii ekologicznych i który został podany w wątpliwość zupełnie niedawno. Jakby starożytni myśliciele nie ustanowili już tego podziału na naturę i kulturę, by go zarówno promować, jak i niepokoić się jego charakterem i zasięgiem; jakby „nowoczesność”, począwszy od renesansu, nie została stworzona także wokół wiedzy, która podkreślała przynależność istot ludzkich do otaczającego je porządku Natury.

Tę narrację o wielkim podziale odnajdujemy tylko nieco zmodyfikowaną nawet u subtelnego Buno Latoura. Według niego nowoczesność okłamała siebie samą, uwierzyła bowiem, że może się odciąć od natury, natomiast w laboratoriach, tyglach tej nowoczesności, naukowcy łączyli byty niebędące ludźmi z ludźmi, ukradkiem tworząc zbiorową hybrydę, pretendując jednocześnie do tego, by oddzielić naturę od społeczeństwa i naukę od polityki. Dlatego według Latoura „nigdy nie byliśmy nowocześni” z punktu widzenia pęknięcia między Naturą a Społeczeństwem i dopiero teraz zaczynamy zdawać sobie z tego sprawę dzięki jego socjologii praktyk naukowych, która pozwala uroczyście zamknąć nawias nieprawdziwej nowoczesności trzech stuleci... a więc raz jeszcze narracja o odkryciu refleksyjności!

Problemem wszystkich wielkich narracji o przebudzeniu, objawieniu czy też zyskaniu świadomości jest to, że są one fałszywe z historycznego punktu

13 Zob. A. Giddens Les Conséquences de ta modernité, L'Harmattan, Paris 1994; U. Beck La Société du risque. Sur la voie d'une autre modernité, Aubier, Paris 2001. Przekłady polskie: A. Giddens Konsekwencje nowoczesności, przeł. E. Klekot, Wydawnictwo UJ, Kraków 2008; U. Beck Społeczeństwo ryzyka. W drodze do innej nowoczesności, przeł. S. Cieśla, Scholar, Warszawa 2004. 
widzenia. Okres między 1770 a 1830 rokiem charakteryzuje się, wprost przeciwnie, jasnym rozumieniem związków natury i społeczeństwa. Na przykład wycinka lasów była postrzegana jako zerwanie organicznego związku między drzewem, społeczeństwem ludzkim i środowiskiem globalnym. Medycyna neohipokratejska badała relacje między ciałem organicznym, ciałem społecznym i ciałem środowiska. Naukowa koncepcja organicystów zaś aż po połowę XIX wieku definiowała Ziemię jako żyjący byt. Wszystko to jest świadectwem przenikania się, obecnego w niektórych ważnych nurtach nowoczesności, środowisk ciała i społeczeństwa oraz dialogu podtrzymującego porządek polityczny i naturalny. Fourier, twierdząc w 1821 roku, że „to planeta jako całość jest zagrożona, a nie tylko niektóre regiony", po prostu czerpał z dużej liczby pism i przestróg naukowych swego czasu.

I to właśnie w tym okresie Europa Zachodnia wciągnęła świat w antropocen! Nie jest to więc narracja o ślepocie, po której nastąpiło przebudzenie, to raczej historia marginalizacji wiedzy oraz ostrzeżeń, historia „nowoczesnego odhamowania"14, którą należy poddać krytyce. Wejście naszej planety w antropocen nie następuje po szalonym modernizmie, ślepym na środowisko, ale - wprost przeciwnie - po dekadach refleksji i niepokojów związanych z degradacją naszej Ziemi czynioną przez ludzi.

Z tego samego powodu Wielkie Przyspieszenie antropocenu po 1945 roku nie przeszło niezauważone przez naukowców i myślicieli tego czasu. Dużo wcześniej niż obrazy Ziemi widzianej z Księżyca bomba atomowa stała się wydarzeniem, które połączyło kondycję ludzką z Ziemią. Dzieła Road to Survival Williama Vogta i Our Plundered Planet Fairfielda Osborna ${ }^{15}$, sprzedane w liczbie 20 i 30 milionów egzemplarzy, koncentrują się wokół kategorii globalnych, takich jak „planeta” czy „Ziemia”, i przestrzegają przed przyszłością światowego ekosystemu oraz jego głębokich konsekwencji ludzkich. Ci autorzy myślą już o ludzkości jako „sile geologicznej”"16. Działalność ludzka i cykle naturalne warunkują się wzajemnie w „całościowym środowisku”, będącym systemem ${ }^{17}$. Po Arrheniusie, tłumaczącym efekt cieplarniany pod

14 Zob. J.-B. Fressoz L'Apocalypse joyeuse: une histoire du risque technologique, Éditions du Seuil, Paris 2012.

15 Zob. F. Osborn Our Plundered Planer, Utile Brown, Boston 1948; W. Vogt Road to Survival, Sloane Associates, New York 1948.

16 Tamże, s. 32, 45.

17 W. Vogt Road to Survival, s. 285. 
koniec XIX wieku, badacze amerykańscy Roger Revelle i Hans Suess, napisali w 1957 roku:

Ludzie przeprowadzają obecnie eksperyment geofizyczny na wielką skalę [...].W ciągu kilku stuleci wysłaliśmy do atmosfery i oceanów węgiel organiczny przechowywany w skałach osadowych przez setki milionów lat. Ten eksperyment, jeśli zostanie odpowiednio udokumentowany, może dać daleko idący wgląd w procesy klimatyczne i meteorologiczne. ${ }^{18}$

Jest zatem błędem historycznym lub karygodną ignorancją utrzymywanie, że „my” wstąpiliśmy w antropocen na początku XIX wieku lub w czasie Wielkiego Przyspieszenia w połowie XX stulecia bez świadomości i wiedzy na temat globalnych zakłóceń ekologicznych.

Dlaczego, można by nam zarzucić, mielibyśmy krytykować antropocenologów, naukowców bądź filozofów, że snują wielką narrację tego rodzaju? W końcu, czy nie jest to konieczne, aby zdemontować opozycyjną wielką narrację Nowoczesności i Postępu? „Zamiast metafizycznej maszyny, jeszcze większa metafizyczna maszyna!"'19. Czy to nie koniec (postrzegany jako uświadomienie ludzkości skali ekologicznych zakłóceń) usprawiedliwia środki? My w to nie wierzymy.

Przede wszystkim dlatego, że ta bajka, zapowiadając zerwanie, tak naprawdę odtwarza światopogląd Nowoczesnych, który krytykuje. Wywodzi się z tego samego porządku historyczności, który zdominował XIX wiek i część $\mathrm{XX}, \mathrm{w}$ którym przeszłość jest oceniana wyłącznie pretekstowo, jako tło lekcji udzielonej przez przyszłość, oraz w reprezentacji czasu jako przyspieszenie jednokierunkowe. Przedstawia „front modernizacji” ${ }^{20}$, porzucając ciemną przeszłość i dążąc ku przyszłości, w której nasza wiedza stanie się globalna i solidna, ostatecznie zmuszając nas do uwzględnienia tego w polityce (ale inaczej niż wcześniej: bez „wielkiego podziału”, bez autorytarnej i zewnętrznej Natury bądź ślepych pewników).Teleologia ekologicznej przyszłości naszego społeczeństwa zastąpi teleologię postępu. Tak oto modernizacyjna bajka zapowiada koniec modernizacji...

R. Revelle, H.E. Suess Carbon Dioxide Exchange between Atmosphere and Ocean and the Question of an Increase in Atmospheric CO2 during the Past Decades, "Tellus" 1957 No. 9, s. 18-27.

B. Latour Enquête sur les modes d'existence. Une anthropologie des Modernes, La Découverte, Paris 2012, S. 34.

Tamże. 
Po drugie, ta narracja, „zapominając” o środowiskowej refleksyjności nowoczesnych społeczeństw, ma tendencję do odpolityczniania kwestii ekologicznych z przeszłości i tym samym utrudnia zrozumienie obecnych problemów. Mówiąc poważnie, antropocen grzebie postmodernistyczne marzenie o społeczeństwie, które w końcu stało się refleksyjne. Kto może nadal wierzyć, że jeśli jednostki, społeczeństwa, państwa i korporacje nie zachowują się w sposób ekologicznie zrównoważony, to dlatego, że wciąż cierpimy na niedostatek wiedzy naukowej, która mogłaby nas przekonać? Zdobycze nauk humanistycznych i społecznych pokazuja, że pewne procesy społeczno-ekonomiczne i kulturowe są o wiele bardziej determinujące niż ilość informacji naukowej: lobbing, storytelling, efekt odbicia, pucz technologiczny, greenwashing [...]. Istnieje cały arsenał umożliwiający ignorowanie ostrzeżeń i protestów, który należy zidentyfikować w przeszłości, by zaproponować jego dynamiczną lekturę, politycznie mniej naiwną niż wielka narracja o przebudzeniu świadomości. [...]

\section{Wielka narracja, w której bohaterami są naukowcy}

Co więcej, czyż przyswajanie troski o środowisko i wiedzy o środowisku z przeszłości przez nieśmiałych i niepewnych "prekursorów" nie prowadzi do przesadnej gloryfikacji wiedzy dzisiejszych naukowców? Wielka narracja antropocenu dzieli antropos, ludzkość, na dwie kategorie: z jednej strony to bezkształtna masa światowej populacji, która stała się czynnikiem geologicznym, nie zdając sobie z tego sprawy, a z drugiej - wąska elita uczonych, dostrzegających dramatyczny i niepewny los planety. Z jednej strony nierefleksyjna grupa zobiektywizowana przez demografię, biologię i ekonomię; z drugiej - idealistyczna historia utkana ze związków intelektualnych, prekursorów i upartego oporu.

WXVI wieku odkryto Amerykę. W XXI wieku nie chodzi o odkrycie nowych ziem, w znaczeniu poszerzenia przestrzeni, ale raczej o spotęgowanie naszego związku z tą Ziemią. [...] Antropocen i Gaja to dwie koncepcje opracowane przez badaczy reprezentujących nauki ścisłe; o wiele bardziej wyprzedzających swój czas niż cała masa intelektualistów, polityków i artystów zainteresowanych tylko historią istot ludzkich. ${ }^{21}$

21 Wywiad cytowany przez W. Zarachowicz, zob. „Télérama” mai 2013 No. 3303, http://www.telerama.fr/idees/gaia-la-terre-mere.96905.php. 
W tego typu proroctwach, będących modernistyczną narracją, która umieszcza specjalistów zajmujących się systemem Ziemi w chwalebnym gronie odkrywców XVI wieku [...], naukowcy są reprezentowani jako ekologiczna awangarda świata. Pojawiają się nie tylko jako rzecznicy Ziemi, ale także jako pasterze opinii publicznej, która jest niedouczona i bezradna. W wielkiej narracji antropocenu ludzie, „,wędrujący lud”, mogą wreszcie „dojść nie do ziemi obiecanej, ale po prostu do Ziemi [...], tak zwanej Gai"22 bądź przeżyć nowy renesans „na nowo łącząc się z biosferą"23.

Oto prorocza narracja, która umieszcza naukowców zajmujących się systemem Ziemi, wraz z ich nowymi zwolennikami z nauk humanistycznych, na stanowisku dowodzenia rozregulowanej planety i jej pogubionej ludzkości. Georząd naukowców! Czy wyrzucając za burtę kategorie „starych nauk społecznych", mających na względzie asymetrię między ludzkimi grupami, trzeba również zrezygnować z demokratycznych ideałów politycznych? Co zostaje dla polityki w skali geologicznej, do której przekonuje nas antropocen? Co możemy jeszcze zrobić w wymiarze indywidualnym i zbiorowym? Ryzyko polega na tym, że antropocen i jego ogromne ramy czasowe znieczulają politykę. Naukowcy zyskaliby pozycję monopolisty zarówno w definiowaniu tego, co się z nami dzieje, jak i tego, co należy zrobić.

Posłuchajmy ekspertów globalnego środowiska, którzy wprowadzili w artykułach z lat 2000 i 2002 koncepcję antropocenu i którzy wyobrażają sobie ratowanie ludzkości przez naukę i inżynierię:

Ludzkość pozostanie główną siłą geologiczną na wiele tysiącleci, może miliony lat, które dopiero nadejdą. Opracowanie i przyjęcie ogólnoświatowej strategii gwarantującej trwałość ekosystemów i chroniącej je przed naciskami wywołanymi przez człowieka będzie jednym z wielkich przyszłych zadań ludzkości, wymagającym intensywnych wysitków badawczych imądrego zastosowania zdobytejw ten sposób wiedzy [...]. To ekscytujące, ale także trudne iśmiałe zadanie czeka na światowa społeczność badaczy i inżynierów, którzy pokierują ludzkością ku globalnemu izrównoważonemu zarządzaniu środowiskiem [wyróż. aut.] $]^{24}$

Przed naukowcami i inżynierami stoi trudne zadanie, aby $\mathrm{w}$ dobie

B. Latour Enquête sur les modes d'existence, s. 34-35.

C. Folke, L, Gunderson Reconnecting to the Biosphere, s. 55.

P.J. Crutzen, E.F. Stoermer The Anthropocene, "Global Change Newsletter" 2000 Vol. 41, s. 18. 
antropocenu pokierować społeczeństwem ku zrównoważonemu zarządzaniu środowiskiem [wyróż. aut.] Będzie to wymagało odpowiednich zachowań ludzkich we wszystkich sferach i może obejmować międzynarodowe projekty geoinżynieryjne prowadzone na dużą skalę, na przykład w celu "optymalizacji” klimatu. ${ }^{25}$

Widzimy tutaj, jak w tym samym czasie, gdy ogłaszany jest antropocen, promowana jest geoinżynieria (zestaw technik do manipulowania klimatem w skali globalnej: emisja aerozoli siarkowych do atmosfery, żelazo w oceanach, odblaskowe satelity wokół Ziemi itp.), mimo jej niepewności i niebezpieczeństw (w przypadku „rozwiązania" z zastosowaniem aerozoli siarkowych można wyobrazić sobie setki tysięcy przedwczesnych zgonów) i mimo istnienia moratorium ONZ na takie interwencje. W czasopiśmie wydawanym przez British Royal Society czterech antropocenologów precyzyjnie wymienia „innowacyjne podejścia”, które zaproponować może technonauka w odpowiedzi na ekologiczny nieład. Chodzi w tym przypadku nie tylko o wielkie systemy technologiczne do obserwacji planety i naukowego ustalenia granic, których ludzkość nie może przekroczyć, ale także o biologię syntetyczną do tworzenia nowych sztucznych form bioróżnorodności, o zarządzanie adaptacyjne z zastosowaniem zasad ekologii i geoinżynierii do działań publicznych.

Czy wtargnięcie natury do polityki oznacza całkowite zawierzenie naukowcom, czy - wręcz przeciwnie - krytykę technonauki i rezygnację z panowania nad Ziemią? Zgodnie z wielką narracją antropocenologów pierwsza opcja wydaje się jedyną możliwą. Jeśli dotychczasowe innowacje rozregulowały planetę, należy zastosować „innowacyjne podejście”, które prezentuje współczesna technonauka! W najważniejszych czasopismach naukowych zajmujących się antropocenem wszystko jest przedstawione tak, jakby wiedza o środowisku i inicjatywy społeczeństwa obywatelskiego nie istniały. Ludy tubylcze walczące ze zniszczeniami na ich ziemiach wywołanymi przez górnictwo lub wydobycie ropy naftowej, społeczności praktykujące ubóstwo z wyboru, jak Degrowth, Transition czy „buen vivir”, młodzi ekolodzy, którzy zawieszają kabiny na drzewach na drodze buldożerów budujących autostrady i lotniska, ruchy krytykujące techniki nuklearne, przestrzenne, komunikacyjne, cyfrowe, bio- i nanotechnologiczne, wszystkie te wspólnoty są absolutnie niewidoczne w wielkiej narracji. Jeśli wierzymy ekspertom antropocenologom, poważne rozwiązania mogą wynikać z dalszych innowacji 
technologicznych w laboratorium, a nie z „oddolnego" alternatywnego eksperymentu politycznego we wszystkich społeczeństwach! [...]

\section{Dyskurs nowej geowładzy}

Przedstawienie Ziemi i jej nowoczesnego rozregulowania zaproponowane przez antropocenologów należy traktować podwójnie poważnie. Z jednej strony gwarantuje ono wiedzę oraz absolutnie niezbędne i zasadnicze ostrzeżenia, z drugiej zaś jest ono produktem zachodniego naturalizmu i kultury naukowej zimnej wojny. Nie może to być zatem jedyny punkt widzenia, unikalne wyobrażenie Ziemi, ani specyficzny sposób zamieszkiwania jej zbiorowo i w pokoju. Istnieje wiele narracji na temat zmiany sposobu egzystencji na naszej Ziemi. W kulturze zachodniej można ich wyróżnić przynajmniej pięć: narracja naturalistyczna, dominująca dziś na scenie naukowej i międzynarodowej; wielka narracja konstruktywistyczna postnatury i „ekomodernizmu” technologicznego „dobrego antropocenu”; wielka narracja ekokatastroficzna, która zakłada upadek cywilizacji; narracja ekomarksistowska i ekofeministyczna. Ale wiele innych narracji, wyobrażeń i kosmologii ma kluczową rolę do odegrania, byśmy mogli mieszkać na Ziemi we właściwy sposób. Potrzebujemy różnorodnych inicjatyw i propozycji, obywatelskich i powszechnych, badających zarysy „lepszego życia za mniej”, a nie tylko „rozwiązań” oferowanych przez wąski krąg planetarnych technokratów. Istotne jest również, by wykluczyć to, co w typowych narracjach antropocenu stanowi część nowej geowładzy w zarodku.

Co rozumiemy przez geowładzę? Jak pokazali historycy (przede wszystkim Michel Foucault), wiedza biologiczna XIX i XX wieku umożliwiła stworzenie nowych obiektów naukowych: „populacji”, „życia” i „rasy”. Wiedza biologiczna zainaugurowała nową formę władzy, biowładzę, której szczególną właściwością jest postrzeganie życia biologicznego jako obiektu i politycznego projektu. Biowładza, charakterystyczna dla epoki przemysłowej i budowy państwa narodowego, miała na celu optymalizację ilości, jakości (higienicznej, fizycznej, intelektualnej, genetycznej itp.), , siły” militarnej (wojna staje się totalna) i produktywności populacji.

Wiedza i wyobrażenia o globalnym środowisku, które pojawiły się już w czasach zimnej wojny, oraz dominujące narracje antropocenu można odczytać jako elementy nowej wiedzy-władzy, która akcentuje nie tylko „bio”, ale także „geo". Po życiu to Ziemia jako całość (od litosfery do stratosfery) staje się obiektem wiedzy ("geowiedza”) i zarządzania („geowładza”). Pojawienie 
się nowych form podmiotowości w postaci „obywateli planety”, wychylenie ekologii ku geologii - czyli zwrot geologiczny - obawy związane z ludzką historią i zjawiskami ekologicznymi, poszerzenie skali czasu, która wydaje się niekompatybilna z działalnością zbiorową i polityczną (jeśli problem jest natury geologicznej, co może zrobić prosty obywatel, jeśli nie zwrócić się do ekspertów?), przesadna interdyscyplinarność globalnych ekspertyz [...] i wreszcie systemy monitorowania planety przez satelitę są oznakami wyłonienia się nowej „geowładzy”, ustanawiającej Ziemię jako „system”, który należy poznać i którym trzeba zarządzać jako całością, we wszystkich jego komponentach i funkcjach.

Prawdą jest, że „imperialna ekologia”26 rozwinęła się w XIX wieku, ale dopiero po II wojnie światowej, z bronią atomową, nowymi instytucjami międzynarodowymi, a przede wszystkim zimną wojną, podczas której postrzegano planetę jako teatr nieuchronnego konfliktu, powstał nowy, globalny system wiedzy-władzy, od podwodnych głębin do Księżyca. Jednocześnie ekologia stała się systemowa i globalna. Biosfera, koncepcja początkowo zaproponowana przez Władimira Wernadskiego w latach 20. XX wieku, została na nowo zdefiniowana przez UNESCO w 1968 roku jako „system żywej materii, substancji, termodynamicznie otwarty i samokontrolujący się, gromadzący i redystrybuujący ogromne zasoby energii" ${ }^{27}$. Uzbrojeni w tę cybernetyczną koncepcję natury, ekologowie [...] uchodzili za globalnych ekspertów, zarządzających "produkcją biologiczną" - to termin często spotykany w ówczesnych artykułach podejmujących problematykę ekologiczną - planety w taki sposób, by pogodzić krótkoterminową rentowność ekonomiczną z długą historią rozwoju ekosystemów, które są gwarantem bogactw naturalnych. [...]

Geowładza opiera się na wspólnej matrycy i mechanizmach, w których wiedza, władza i poddani nowego typu tworzą całość. Geowładza nakłania własnych podwładnych, antropos, do "ponownego połączenia się z biosferą" i dąży do ustanowienia coraz większej liczby ludzkich problemów możliwych do rozwiązania jedynie w skali globalnej i dzięki zastosowaniu rozwiązań technicznych. Geowładza jest „przestrzenią obliczeniową” (Foucault) na

26 Zob. P. Anker Imperial Ecology: Environmental Order in the British Empire. 1895-1945, Harvard University Press, Cambridge, MA 2001.

27 Utilisation et conservation de la biosphère. Actes de la Conférence intergouvemementale d'experts sur les bases scientifiques de l'utilisation rationnelle et de la conservation des ressources de la biosphère, Unesco, Paris 1970, s. 15. 
poziomie „systemu Ziemi”: rachunki przepływów dóbr materialnych i energetycznych oraz „naturalnego kapitału”, rynki „usług ekosystemowych”, kontrola i zarządzanie komponentami i procesami „systemu Ziemi”, instrumenty uprzedzania, przewidywania i globalnej symulacji, a także zapewnienie współmierności miejsc w przestrzeni izonomicznej.

Geowładza, w obliczu trwającej zmiany systemu Ziemi, dąży do regulacji termostatu globu i, w tym celu, do kontrolowania Ziemi przez nową inżynierię warstw ludzkich. Projekt geoinżynierii jest konkretnym wcieleniem rodzącej się geowładzy. Jego celem jest "poprawa środowiskowych cech atmosfery" ${ }^{28}$, a nawet całego funkcjonowania planety, w tym biosfery. Jeszcze bardziej niż w przypadku testów jądrowych lub wyimaginowanej „Ziemi statku kosmicznego" cała Ziemia jest tu wyraźnie uprzedmiotowiona jako obiekt eksperymentu i kontroli.

Projekt geoinżynierii klimatycznej sięga czasów zimnej wojny. Na przykład technika "globalnego zarządzania promieniowaniem słonecznym" przez rozpraszanie aerozoli w górnych warstwach atmosfery ma swoje źródło w propozycji radzieckiego naukowca Michaiła Budyko zaprezentowanej na konferencji w Leningradzie w 1961 roku, która była poświęcona "problemom kontroli klimatu" i przestrzegała, że ludzkie działania mogą wkrótce zmienić równowagę radiacyjną Ziemi. Kolega Budyko - Shvets - zaproponował z kolei wstrzyknięcie 36 milionów ton aerozoli do stratosfery w celu zmniejszenia promieniowania słonecznego o 10\%. Analogiczny projekt można znaleźć w pismach Lovelocka, który skończywszy pracę dla NASA nad programem kolonizacji Marsa, opublikował w 1984 roku fikcyjne dzieło i wyobrażał w nim sobie użycie pocisków międzykontynentalnych rozrzucających setki ton chlorofluorowęglowodorów wokół Czerwonej Planety w celu wywołania efektu cieplarnianego, który umożliwiłby jej zamieszkanie. Liczne projekty, powstałe w Stanach Zjednoczonych, a potem w Związku Radzieckim i Chinach, zasiewania chmur za pomocą balonów, samolotów lub wszelkiego rodzaju pocisków świadczą $\mathrm{o}$,prawdziwej wojnie toczonej w atmosferze" ${ }^{29} \mathrm{w}$ kulturze manipulacji systemem Ziemi, wzmocnionej jeszcze przez kontekst zimnej wojny.

Po upadku bloku sowieckiego projekt geoinżynierii został poddany recyklingowi w 1992 roku w raporcie US Academy of Sciences jako środek

28 Zob. G.M. Batanov, I.A. Kossyi, V.P. Silakov Gas-Discharge Method for Improving the Environmental Characteristics of the Atmosphere „ "Plasma Physics Reports” 2002 Vol. 28, No. 3, s. 204-228.

29 S. Grevsmühl La Terre vue d'en hau. L'Invention de l'environnement global, Éditions du Seuil, Paris 2014. 
walki ze zmianami klimatu. Podobnie, jeśli w pierwszej dekadzie XXI wieku Paul Crutzen w końcu przyłączył się do geoinżynierii, postąpił tak dlatego, że został wykształcony w kulturze zimnej wojny, która uczyniła całą Ziemię (nawet Marsa!) teatrem interwencji na dużą skalę (w latach 8o. Crutzen pracował nad pierwszym scenariuszem „nuklearnej zimy”, będącej konsekwencją wojny jądrowej).

W lutym 2014 roku John Kerry przedstawił zmiany klimatyczne wraz z innymi zagrożeniami, takimi jak epidemie i terroryzm, jako „być może najbardziej przerażającą broń masowego rażenia" ${ }^{30}$. Wydaje się, że w dobie "globalnego zarządzania środowiskiem" powróciła logika wojny, całkowitej kontroli nad planetą w imię stanu wyjątkowego w odpowiedzi na ewentualną przemoc wynikającą z konsekwencji globalnych zakłóceń ekologicznych i podsycającą nowe podziały geopolityczne. Projekty, z pozoru tak odmienne jak geoinżynieria, mechanizmy REDD, które wprowadzają lasy na globalny rynek węgla, marzenia o terraformowaniu itp., są wytworem taj samej logiki sytuacji kryzysowej („kryzys klimatyczny”), jeśli nie wprost „stanu wyjątkowego" [...].Trudno przewidzieć przyszłość geowładzy. Czy będzie wielostronna i będzie opierać się na ONZ? A może regionalna bądź nawet prywatna? (już podejmowano pojedyncze eksperymenty korporacyjne z wysiewem oceanów). W połączeniu z logiką suwerenności i imperatywem bezpieczeństwa narodowego mogłaby zostać świetnie wykorzystana w sposób jednostronny; zaś w połączeniu ze współczesną doktryną neoliberalną i poszerzeniem sfery własności prywatnej mogłaby doprowadzić do postrzegania rynku jako najlepszego kalkulatora ratującego planetę poprzez wycenę „kapitału naturalnego" i ,usług ekosystemowych" oraz uczyniłaby przepływy finansowe zarządcami przepływów biogeochemicznych [...].

Dominująca narracja antropocenologów już teraz podsuwa zarodkową redefinicję tego, czym jest byt ludzki na Ziemi. Temat antropocenu i geowładzy jest elementem "geoprzeznaczenia" ludzkości jako siły geologicznej, która jest zarówno heroiczna, jak i niezrównoważona, budzi podziw i przerażenie, jednocześnie ukrywając pod wspólnym sztandarem gatunku pewną liczbę niesprawiedliwości społeczno-środowiskowych. Co więcej, temat antropocenu pojawia się pod postacią ekoobywatela optymalizującego swoje kredyty

30 Kerry calls climate change a weapon of mass destruction, déridés skeptics, "The Washington Post" 16 February 2014, www.washinglonpost.com/world/asia_pacific/kerry-calls-climatechange-a-weapon-of-mass-destruction-derides-skeptics/2014/02/16/1283b168-971a-11e3ae45-458927ccedb6jttory.html (22.02.2016). 
węglowe, zarządzającego indywidualnym śladem węglowym (i zarządzanego przez własną refleksyjność środowiskową). Jest to istota podłączona do przepływów „usług ekosystemowych”, w które zaopatrują ją różne segmenty systemu Ziemi. I wreszcie, temat antropocenu został stworzony przez bierną opinię publiczną, pozostawiającą rozwiązania ekspertom geokratycznym.

Od lat 70. teoretycy polityki ekologicznej sygnalizowali niebezpieczeństwa związane z tak pojętą geowładzą. André Gorz nazwał ją „ekofaszyzmem”, natomiast Ivan Illich w książce Tools for Conviviality wydanej w 1973 roku widział w niej „dobrze zorganizowaną elitę [...], przemysłowe antidotum na wyobraźnię rewolucyjną. Namawianie ludzi do zaakceptowania ograniczeń produkcji przemysłowej bez zakwestionowania podstawowej struktury społeczeństwa przemysłowego nieuchronnie zapewniłoby większą władzę biurokratom optymalizującym wzrost, a ze społeczeństwa uczyniłoby ich zakładnika”"31. Zaś Félix Guattari mówił o wiedzy i władzy „naukowego” zarządzania środowiskiem jako „ekologii mechanicznej”, niewystarczającej lub nawet niebezpiecznej, jeśli nie zostałaby uzupełniona i kontrolowana przez "ekologię społeczną" $i$ „ekologię mentalną" lub ekozofię ${ }^{32}$.

A co, jeśli „Ziemia widziana z nieba” i wielka narracja „interakcji między gatunkiem ludzkim a systemem Ziemi" nie byłyby najciekawszymi sposobami opowiedzenia tego, co się z nami stało w ciągu ostatnich dwóch i pół wieku, oraz tego, jakie może być nasze geohistoryczne przeznaczenie? Być może powinniśmy zaakceptować antropocen bez ulegania dominującej narracji antropocenologów? Bez przekazywania pełnych uprawnień ekspertom i utraty zasobów przypisanych każdej społeczności ludzkiej, każdej wspólnocie społeczno-ekologicznej, które są w swojej różnorodności i lokalnych uwarunkowaniach niezbędnymi motorami sprawiedliwej przemiany ekologicznej w skali światowej. [...] „Wynalazcy” antropocenu, naukowcy badający system Ziemi, którzy ostrzegają nas przed zakłóceniami ekologicznymi, są bardzo przydatni, gdy mówią nam o niebezpieczeństwie. Jednak [...] stoją oni „po drugiej stronie”, są niezdolni do odczucia ciepłej obecności świata,,ekonomii radości” $i$ „przyjemnych kolorów”. Jeśli niebezpieczeństwo jest realne, [poeta] ogłasza opór społeczeństwa, które odmawia zrzeczenia się swojej autonomii i kultury, by pokłonić się heteronomii ekotechnokratycznego rządu.

Przełożył Piotr Śniedziewski

31 I. Illich La Convivialité, Éditions du Seuil, Paris 1973, S. 154.

32 Zob. F. Guattari Les Trois Écologies, Galilée, Paris 1989. 


\section{Abstract}

\section{Christophe Bonneuil, Jean-Baptiste Fressoz}

CENTRE NATIONAL DE LA RECHERCHE SCIENTIFIQUE, PARIS

Scientists and Anthropos: Anthropocene or Oligantopocene?

This is a translation of passages from the chapter"Le savant et l'antrophos: Anthropocène ou Oliganthropocène" from Christophe Bonneuil and Jean-Baptiste Fressoz's book L'Événement Anthropocène: La Terre, l'histoire et nous, Paris: Seuil, 2016., pp. 83-118 (The Shock of the Anthropocene: The Earth, History and Us in David Fernbach's English translation).

In their groundbreaking book The Shock of the Anthropocene, Bonneuil and Fressoz discuss the relationship between science as a modern institution of organising individual life in its biological and organic dimension and social life, which is subordinated to faith in technological progress and the paradigm of infinite capital accumulation. The authors propose that the anthropocene is not only the peak and negative point of the project of modernity - a different way of thinking about science and new scientistic practices will be more than utopian visions - above all, they will be ways to maintain the diversity of life and to reverse humankind's separation from the world.

\section{Keywords}

anthropocene, environmental awareness, technoscience, geopower, postnature 